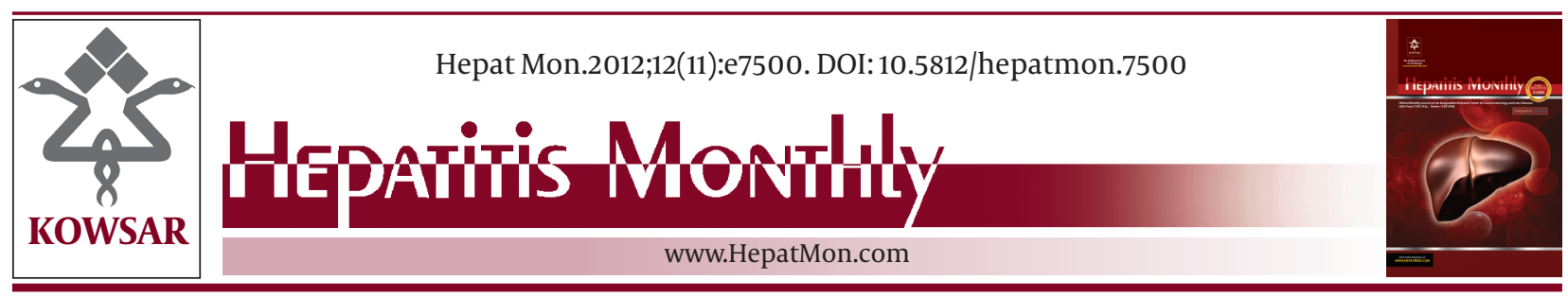

\title{
Dismissing Appropriate Statistical Analysis
}

\author{
Mohammad Reza Ghadir ${ }^{*}$ \\ ${ }^{1}$ Gastroenterology Section, Department of Internal Medicine, Faculty of Medicine, Qom University of Medical Sciences, Qom, IR Iran
}

\section{A R T I C L E I N F O}

Article type:

Reply

Article history:

Received:10 Jul 2012

Revised: 20 Jul 2012

Accepted: 02 Aug 2012

Keywords:

Hepatitis D

Hepatitis B Virus

Prevalence

Iran

\section{Dear Editor,}

We are thankful to the referees Dr. Mohamad Amin Pourhoseingholi et al. and the Editor for pointing out some valuable suggestion and important notes needed in the manuscript (1). The major concern of reviewer was about the positive Hepatitis D patient (2). Due to high number of cases in our study, the prevalence of Hepatitis $\mathrm{D}$ is very low (3).

1) The only positive Hepatitis D is a 31 year-old woman. We have mentioned that she was an Afghanian lady but we have considered her native because she has Iranian ID Card, although we have not assessed her ancestry.

2) As the reviewer has mentioned, chi square test is impractical in the present study so fisher exact test is used. We have mentioned to this important note in the methods and conclusion sections.

3) It has mentioned that repeated test is performed to assess association between Hepatitis D and Tatto. So P value of likelihood ratio is not reported and both of P values are related to fisher exact test (3).
- Please cite this paper as:

Ghadir MR. Dismissing Appropriate Statistical Analysis. Hepat Mon. 2012;12(11). DOI: 10.5812/hepatmon.7500

Published by Kowsar Corp, 2012. cc 3.0.

\section{Authors' Contribution}

Mohammad Reza Ghadir contributed 100\% to prepare this reply.

\section{Financial Disclosure}

None declared.

\section{References}

1. Pourhoseingholi MA, Baghestani AR, Vahedi M. When Appropriate Statistical Analysis is Dismissed. Hepat Mon. 2012;12(8):e7024.

2. Jacobson IM, Dienstag JL, Werner BG, Brettler DB, Levine PH, Mushahwar IK. Epidemiology and clinical impact of hepatitis D virus (delta) infection. Hepatology. 1985;5(2):188-91.

3. Ghadir MR, Belbasi M, Heidari A, Sarkeshikian SS, Kabiri A, Ghanooni AH, et al. Prevalence of hepatitis d virus infection among hepatitis B virus infected patients in qom province, center of iran. Hepat Mon. 2012;12(3):205-8.

\footnotetext{
* Corresponding author:Mohammad Reza Ghadir, Gastroenterology Section, Department of Internal Medicine, Faculty of Medicine, Qom University of Medical Sciences, Qom, IR Iran. Tel:+98-9121510382, Fax:+98-2512909288,E-mail: ghadir@muq.ac.ir

DOI:10.5812/hepatmon.7500

Copyright@ 2012 Kowsar Corp. All rights reserved.

This is an Open Access article distributed under the terms of the Creative Commons Attribution License (http://creativecommons.org/licenses/by/3.0), which permits unrestricted use, distribution, and reproduction in any medium, provided the original work is properly cited.
} 